Merkel, Angela 2010: Regierungserklärung zum AfghanistanKonzept der Bundesregierung von Bundeskanzlerin Merkel vom 28. 1.2010. Stenografische Mitschrift des Deutschen Bundestages. Online verfügbar: http://www.bundesregierung.de/ Content/DE/Regierungserklaerung/2010/2010-01-28-merkelerklaerung-afghanistan.html.

Mohrmann, Günter 2009: Auslandseinsätze und zivil-militärische Zusammenarbeit. Herausforderungen - Entwicklungslinien - Wirkungen - Perspektiven. In: Jaberg, Sabine/Biehl, Heiko/Mohrmann, Günter/Tomforde, Maren (Hrsg.) 2009: Auslandseinsätze der Bundeswehr. Sozialwissenschaftliche Analysen, Diagnosen und Perspektiven. Berlin: 93-119.

Münch, Philipp 2008: Freund oder Feind? Sicherheitsbedrohungen bei deutschen Auslandseinsätzen aus Sicht der Bundeswehr. Masterarbeit Universität Hamburg.

NATO 2001: MC4II/I. NATO Military Policy on Civil-Military Co-operation. Brüssel: NATO. Online verfügbar: http://www. nato.int/ims/docu/mc411-1-e.htm.

Niebel, Dirk 2010: Interview im Deutschlandradio vom 28. Januar 2010. Online verfügbar: http://www.dradio.de/dlf/sendungen/interview_dlf/1114334/.

Paul, Michael 2008: CIMIC am Beispiel des ISAF-Einsatzes. Konzeption, Umsetzung und Weiterentwicklung zivil-militärischer Interaktion im Auslandseinsatz. SWP-Studie S 31. Berlin.
Piiparinen, Touko 2007: A Clash of Mindsets? An Insider's Account of Provincial Reconstruction Teams. In: International Peacekeeping (1): 143 - 157.

Preuß, Hans-Joachim 2008: Zivil-militärische Zusammenarbeit in Afghanistan. Eine Zwischenbilanz. In. Zeitschrift für Außenund Sicherheitspolitik (1): 26-35.

Raschke, Thomas/Tils, Ralf 2007: Politische Strategie. Eine Grundlegung. Wiesbaden.

Schröter, Leonie 2010: Der Ressortkreis Zivile Krisenprävention. Untersuchung einer interministeriellen Zusammenarbeit innerhalb der deutschen Außen- und Sicherheitspolitik. Magisterarbeit Universität Münster.

Verband Entwicklungspolitik Deutscher Nichtregierungsorganisationen (VENRO) 2009: Fünf Jahre deutsche PRTs in Afghanistan. Eine Zwischenbilanz aus Sicher der deutschen Hilfsorganisationen. Positionspapier 1. Online verfügbar: http://www. venro.org/fileadmin/Publikationen/Afghanistan-Positionspapier_PRT.pdf.

Vogler, Kathrin 2004: Wider die militärische Umarmung von Friedens- und Menschenrechtsprojekten. Netzwerk Friedenskooperative. In: Friedensforum (3). Online verfügbar: http://www. friedenskooperative.de/ff/ff04/3-55.htm.

\title{
Pakistan's Foreign Policy between India and Afghanistan
}

\section{Christian Wagner*}

\begin{abstract}
In the 1990s the Pakistani military has linked relations towards Afghanistan with the conflict with India over Kashmir. Afghanistan is perceived under the lens of strategic depth in order to prevent an encirclement by India. The strategy had been successful in the 1990s but has backfired after 9/11. The attacks of Taliban groups pose a growing threat to state and society in Pakistan. But Pakistan's foreign and security policy is still dominated by the military whereas the civilian government is not in a position to reformulate the foreign policy towards the neighbours that would favour closer economic cooperation.
\end{abstract}

Keywords: Pakistan, Afghanistan, India, military, Taliban

Pakistan, Afghanistan, Indien, Militär, Taliban

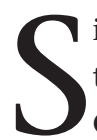

ince many years Pakistan is pursuing an ambiguous policy towards Afghanistan and the international community. ${ }^{1}$ On the one hand, the Af-Pak concept of President Obama of 2009 has acknowledged Pakistan's strategic importance for stability in Afghanistan. On the other hand, the support and toleration of militant Islamic groups in the Federally

* Christian Wagner is Head of the Asia Division at the Stiftung Wissenschaft und Politik (SWP) in Berlin.

1 This contribution is an updated version of Pakistan's Afghanistan Policy in the Shadow of India, in: Hans-Georg Ehrhart/Charles C, Pentland (eds.), The Afghanistan Challenge. Hard Realities and Strategic Choices, McGill-Queen's University Press 2009, pp. 113-127.
Administered Tribal Areas (FATA) by Pakistani agencies are hampering the reconstruction in Afghanistan. ${ }^{2}$ The picture gets more complex because Pakistan is more and more suffering under attacks of Taliban groups. They have extended their military operations to the urban centres of Punjab, the heartland of Pakistan, indicating that the military and the

2 The support was recently confirmed by General Pervez Musharraf who was Chief of Army Staff (COAS) until 2007, see ,Pakistan is Always Seen as the Rogue', SPIEGEL Interview with Pervez Musharraf, in: http://www.spiegel. de/international/world/0,1518,721110,00.html (accessed 14 October 2010); Waldman, Matt, The Sun in the Sky: The Relationship between Pakistan's ISI and Afghan Insurgents, London 2010 (Crisis States Discussion Papers 18). 
Inter-Services Intelligence (ISI) have lost control over parts of these groups. It seems that the strategy of the Pakistani military, to link its relations to Afghanistan with Pakistan's conflict with India over Kashmir during the early 1990s, has partly failed and turned against the Pakistani state and society. In order to analyze the regional power play, this article will first discuss the domestic role of the Pakistani military and then highlight Pakistan's changing relationship with India and Afghanistan.

\section{Pakistan's Domestic Development: The Supremacy of the Military}

Pakistan was established as a separate state for the Muslims of the Indian subcontinent. The new state was formed of the Muslim majority provinces of British India. The eastern and western parts were separated by more than 1500 kilometres of Indian territory. The independence of India and Pakistan in August 1947 was accompanied by large resettlements. About fifteen million Hindus, Sikhs and Muslims left their homes to find new residences in one of the two new states. The migration was overshadowed by riots and massacres of religious fanatics whereby approximately 500,000 people were killed.

Afghanistan was critical on the creation of Pakistan and raised territorial claims on the Pashtun-majority areas in the North West Frontier Province (NWFP). The Afghan government refused to recognize the Durand Line although the Pashtun tribes in NWFP and FATA supported the accession to Pakistan with a referendum in July 1947. Afghanistan was the only country that voted against Pakistan's entry into the United Nations (UN). ${ }^{3}$

The difficult process of state- and nation-building hampered the democratic development in Pakistan. ${ }^{4}$ The new state was confronted with the territorial disputes with India over Kashmir and with Afghanistan over the Pasthun areas. The Muslim League under the leadership of Mohammed Ali Jinnah, which had achieved independence from the British and the Indian National Congress, migrated from North India to West Pakistan and settled as Mohajirs in the new capital of Karachi. However, the idea of Pakistan had only found limited support among the rural elites of Punjab and Sindh, which formed the biggest provinces in West Pakistan. The leadership of the Muslim League was unable to assume a similar role comparable to the Congress Party's in India. Moreover, the two parts of Pakistan had different cultural and linguistic traditions. The majority population of Bengalis in East Pakistan was underrepresented in the army and administration but contributed a large proportion to the economy. Their demands for greater economic and political representation became therefore one of the central domestic conflicts. Pakistan's first constitution was adopted only in 1956 but the first elections were called off after the military coup of General Ayub Khan in October 1958.

3 See S.M. Burke and Lawrence Ziring, Pakistan's Foreign Policy: An Historical Analysis (Oxford, New York 1994), p. 70.

4 For an overview of the historical developments see Stephen P. Cohen, The Idea of Pakistan, Washington 2005; Christophe Jaffrelot (ed.), Pakistan: Nationalism without a Nation? London 2002; Ian Talbot, Pakistan, A Modern History London 1999; Philip Oldenburg, India, Pakistan, and Democracy. Solving the Puzzle of Divergent Paths, Abingdon, New York 2010.
The first democratic elections in 1970 brought a clear mandate for the Awami League (AL) from East Pakistan which had called for greater regional autonomy. Yet, the political and military elite of West Pakistan were not willing to transfer power to the AL. In spring 1971 government negotiations broke down and the Pakistani army advanced against the AL in East Pakistan. The civil war forced thousands of refugees into India which supported the East Pakistani guerrillas and intervened militarily in December 1971.

The war became a military, political and ideological defeat for Pakistan. The army had to surrender and more than 90,000 Pakistani soldiers became prisoners of war in India. Politically, the independence of East Pakistan showed that military rule had been unable to find political solutions in the complex process of state- and nation-building. Ideologically, the creation of Bangladesh shattered Pakistan's idea of being the sole homeland for Muslims in South Asia. The ethnic identity of the Bengalis in East Pakistan proved to be a stronger political bond than the common religious identity.

Yet, the military defeat of 1971 did not end the dominance of the military in Pakistani politics. The tension between national identity, which should be based on religion and regional ethnic identities, led to a series of conflicts in Pakistan. Prime Minister Zulfikar Bhutto, having won the 1971 election with his Pakistan Peoples Party (PPP) in West-Pakistan, promoted the concept of Islamic Socialism in order to strengthen the national identity. However, insurgencies among the Baluchis, Sindhis and Pashtuns against the dominance of the Punjabis strengthened again the image of the army as guardian of national unity. ${ }^{5}$

After manipulations in the 1977 elections General Zia-ul Haq conducted a second coup against Prime Minister Bhutto. In order to increase the legitimacy of his regime Zia-ul Haq amended the constitution so that power was shifted to the presidency and promoted a policy of Islamization. ${ }^{6}$ After Zia-ul Haq's death in an air crash in 1988 the second transition towards democracy took place. The PPP under the leadership of Benazir Bhutto won the election in 1988, but the military continued to influence domestic developments and could not be controlled by the political parties. ${ }^{7}$ Until the third coup of General Musharraf against Prime Minister Nawaz Sharif in October 1999, none of the elected governments finished its term and were dismissed due to bad governance and corruption.

The elections of 2008 ended Musharraf's rule and brought back a democratically elected government. However, the elections did not change the fundamental constellations of the political system which is characterized by the lack of supremcy of the government vis-à-vis the military. More than 60 years after independence Pakistan seems to have developed from a "garrison state" 8 of the 1960s into a garrison democracy. The four walls of Pakistan's garrison democracy in the field of security, politics, economics, and identity consist of the

5 See Tahir Amin, Ethno-National Movements of Pakistan: Domestic and International Factors, Islamabad 1988.

6 See Louis D. Hayes, The Struggle for Legitimacy in Pakistan, Lahore 1986.

7 See Pervaiz Iqbal Cheema, The Armed Forces of Pakistan, Oxford/Karachi 2006, p. 43; Revisiting Mehrangate: hating the PPP, in: Daily Times, 28 August 2008 .

8 See Robert Laporte, Jr., "Succession in Pakistan: Continuity and Change in a Garrison State," Asian Survey 9, 11 (November 1969), pp. 842-861. 
discourses and institutions through which the armed forces have shaped public perception and which set the limits for a democratic development.

The role and predominance of the military is most evident in the security field. The size of the armed forces and the discourse on national security are mostly undisputed. Politically, the armed forces have ruled Pakistan for 32 out of 50 years in the period between 1958 and 2008. There is no noticable parliamentary control of the military budget or the various intelligence services. Moreover, the weakness of the political parties, which have often been instrumentalized and co-opted by the military and the ISI, have helped to give legitimacy to military rule. The creation of the National Security Council (NSC) in 2004 has even institutionalized the role of the military in political affairs. Economically, the military has developed into the biggest entrepreneur, for instance in the transport business, and became the largest landowner. ${ }^{9}$ The perceived threat from India legitimizes a high level of military expenditure and has slowed down investment in health and education so that Pakistan ranks only on position 141 of the Human Development Index (HDI) in 2007. Finally, the military rulers have shaped the discourse on national identity. The perceived threat from India has helped to establish an enemy image in order to counter ethnic and social cleavages. Zia-ul Haq's policy of Islamization fostered Islamic groups, whereas Musharraf promoted the concept of "enlightened moderation" in order to claim leadership in questions of national identity. ${ }^{10}$

\section{Pakistan's Relations with India and Afghanistan until 1989}

Since 1947 the Kashmir issue and relations with India have dominated Pakistan's foreign policy. The territorial dispute was overlayed by an ideational conflict because Kashmir was perceived as a symbol of both Pakistani and Indian founding ideas. For Pakistan, Kashmir with its Muslim majority population was a symbol for the two-nation theory and should therefore be part of the new state. For India, Kashmir was a symbol for the secular character of the new state that was open for all religious communities. ${ }^{11}$

After the outbreak of a rebellion in Kashmir in autumn 1947 the Maharajah of Kashmir joined the Indian Union in October. In return, the Indian government dispatched troops to suppress the insurgents. The fighting escalated into the first war between India and Pakistan. In December 1947 Indian Prime Minister Nehru brought the issue before the United Nations (UN) and suggested a referendum on Kashmir's future status. India's attempt to convict Pakistan's alleged aggression failed, but Nehru's demand for a referendum was included in the UN resolutions. The ceasefire of January 1949 divided Kashmir

9 See Ayesha Siddiqa, Military Inc., Inside Pakistan's Military Economy, London 2007.

10 See "Enlightened Moderation," http://www.presidentofpakistan.gov.pk/EnlightenedModeration.aspx [accessed 11 July 2007].

11 On the development of the Kashmir conflict, see Alastair Lamb, Birth of a Tragedy: Kashmir 1947, Hertingfordbury 1994; Robert G. Wirsing, Kashmir: In the Shadow of War - Regional Rivalries in a Nuclear Age, New York/London 2003; Sumantra Bose, Kashmir: Roots of Conflict, Paths to Peace, Cambridge 2003. into two parts that are controlled by India and Pakistan. The referendum has not been conducted because neither Pakistan nor India has implemented the preconditions.

In the mid-1950s the conflict with India prompted Pakistan to join Western defence alliances like the South East Asia Treaty Organisation (SEATO) and the Central Treaty Organisation (CENTO). Since the early 1960s Pakistan also developed good relations with China, which had defeated India in the border war of 1962. Besides, China had territorial claims in Kashmir in order to secure access into Tibet so that Pakistan ceded parts of Kashmir to China in 1963.

After Nehru's death in 1964, Pakistan thought to exploit India's weakness to solve Kashmir. Guerrilla fighters infiltrated the Indian part of Kashmir in 1965 (Operation Gibraltar) in order to trigger a revolt against India, which should be supported by an intervention of the Pakistani army. ${ }^{12}$ The strategy backfired because the insurgents found hardly any support among the Kashmiris. The second India-Pakistan war ended in September 1965 after a UN resolution and an arms embargo by the USA against both countries.

The third war with India was sparked off by the civil war in East Pakistan in 1971. Despite the military defeat in December 1971 Pakistan's Prime Minister Zulfikar Ali Bhutto achieved a political success. In the Simla Treaty of July 1972 Indian Prime Minister Indira Gandhi following Bhutto's appeal, agreed not to transform the Line of Control (LoC) in Kashmir into an international border. ${ }^{13}$

The next military escalation developed only in the mid-1980s. At the beginning of the decade India accused Pakistan of supporting militant Sikhs fighting for an independent state. In spring 1984, Indian and Pakistani troops occupied parts of the Siachen glacier in Kashmir where the LoC had not been demarcated because of the hostile natural environment. India's large-scale military exercise in 1986-87 ("Brasstacks") brought a further deterioration of the bilateral relations. Pakistan perceived it as preparation for an attack and mobilised its troops. ${ }^{14}$ During the crisis A.Q. Khan, the father of Pakistan's nuclear programme, revealed that his country already possessed nuclear weapons. For the first time there was a danger of nuclear escalation between India and Pakistan. ${ }^{15}$

Pakistan's relations with Afghanistan were also difficult. Prince Mohammed Daoud who was prime minister from 1954 to 1963 and became president after the coup from 1973 to 1978 continually called for greater autonomy for the Pashtuns in Pakistan. In return Pakistan supported the Afghan opposition against Daoud and granted asylum to his cousin King Zahir after the 1973 coup d'etat. ${ }^{16}$ In the 1970s the Bhutto

12 See Shuja Nawaz, Crossed Swords. Pakistan, its Army, and the Wars Within, Oxford 2008, pp. 205ff.

13 See Stanley Wolpert, Zulfi Bhutto of Pakistan: His Life and Times, New York/ Oxford 1993, p. 191-192; Amitabh Matoo, "Next Steps in Kashmir" in Karan R. Sawhny (ed.), Kashmir: How Far Can Vajpayjee and Musharraf Go? New Delhi, 2001, pp. 27-44.

14 See Hasan Askari Rizvi, "Pakistan-India relations in the Eighties," Regional Studies 13 (Islamabad, Summer 1990), pp. 3-31.

15 See Kanti P. Bajpai, P.R. Chari, Pervaiz Iqbal Cheema, Stephen P. Cohen and Sumit Ganguly, Brasstacks and Beyond, New Delhi 1995.

16 See Olivier Roy, The Taliban: A Strategic Tool for Pakistan, in Christophe Jaffrelot (ed.), Pakistan: Nationalism without a Nation? London 2002, p. 150 
government supported small revolts in eastern Afghanistan. ${ }^{17}$ After the Soviet invasion of Afghanistan in 1979 Pakistan received considerable military and financial support from the USA, Saudi Arabia and the Gulf States to support the Afghan Mujahideen which were trained by the ISI.

\section{Relations between Pakistan, India and Afghanistan between 1989 and 2001}

Pakistan's relations with India and Afghanistan were largely independent from one another but underwent a fundamental change after the withdrawal of the Soviet Union from Afghanistan in the late 1980s. Aslam Beg, following Zia-ul Haq as Chief of Army Staff (COAS) in 1988, outlined the new strategy of "strategic depth" in which Afghanistan should act as Pakistan's hinterland. Afghanistan was to serve as a backyard and safe haven for militant groups which could be used against India. ${ }^{18}$ Pakistan's strategy of using militant Islamic groups to further its foreign policy interests vis-à-vis India and Afghanistan reached its peak in the 1990s.

In Kashmir the ISI supported the local protest against the rigged assembly elections in 1987 and helped to establish militant groups like Hizb-ul-Muhahideen (HM) which demanded the Islamization and accession of Kashmir to Pakistan. Moreover, the ISI sent foreign fighters from the Middle East that had fought in Afghanistan to J\&K. ${ }^{19}$ India deployed more than 600,000 soldiers in Kashmir to suppress the rebellion, which led to an escalation of violence and a deterioration of the human rights situation in the 1990s.

The atomic tests of India and Pakistan in May 1998 raised the danger of a nuclear confrontation. In February 1999 the prime ministers of India and Pakistan signed the Lahore Declaration, which should introduce a new phase of cooperation. But the Pakistani military had already started an infiltration into the Indian part of Kashmir in the winter of 1998/99 which led to the Kargil War with India in May/June 1999. The war abruptly ended the new rapprochement, although Pakistan had to withdraw its troops under pressure from the United States. Moreover, the Kargil war showed that the nuclear deterrence was not able to guarantee a durable stability but opened the door for non-conventional military warfare. Politically, Pakistan hoped that this strategy would help to internationalize the Kashmir issue.

After the withdrawal of the Soviet Union, a civil war broke out in Afghanistan between the various ethnic groups and warlords. Since the 1990s Pakistan supported the Taliban which had been educated in Madrassas in Pakistan. ${ }^{20}$ The Taliban captured Kabul and took over the government in 1996. Pakistan was one of the few countries to recognize Afghanistan's new government. The strategic rationale for the Pakistan military was that the Taliban

17 See Marvin Weinbaum, Pakistan and Afghanistan: Resistance and Reconstruction, Lahore 1994, p. 5.

18 See Rifaat Hussein, Pakistan's relation with Afghanistan: Continuity and Change, Strategic Studies 22 (Islamabad, Winter 2002), pp. 43-75.

19 See "Hizbul chief admits to Pak military support in Kashmir," The Tribune, 19 March 2008.

20 See Roy 2002, p. 154. should first secure the strategic depth. Second, they should limit India's influence in Afghanistan which had supported the Northern Alliance in the Afghan civil war. Finally, the religous orientation of the Taliban should act as a counterweight against any claims of Pashtun ethno-nationalist groups.

\section{The repercussions of $9 / 11$}

Pakistan's strategy to support militant Islamist groups in order to pursue its foreign policy objectives regarding India and Afghanistan suffered a setback after 9/11. First, Musharraf joined the War on Terror and Pakistan became a frontline state in U.S. foreign policy again. But he continued to support militant Kashmiri groups like Lashkar-e-Toiba (LeT) and Jaishe-Mohammed (JeM) which attacked the Indian parliament on 13 December 2001. In reaction to the failed attack India threatened military strikes against the infrastructure of the militant groups in Pakistan. The crisis between both countries, which included the danger of a nuclear confrontation, could be settled by diplomatic interventions of the United States and Great Britain in summer 2002.

Surprisingly the Indian Prime Minister Vajpayee offered new talks with Pakistan in April 2003. At the summit in January 2004 Musharraf and Vajpayee agreed on a composite dialogue in order to discuss all outstanding issues like Kashmir, which was important for Pakistan, and terrorism, which was important for India. In the joint statement Musharraf pledged that Pakistani territory would not be used for terrorist attacks against India. ${ }^{21}$

Several factors seemed to have contributed to this unprecedented change of Pakistan's foreign policy. First, the 1999 war and the 2002 crisis had not brought any successes for Pakistan to internationalize Kashmir. The United States and the international community had signalled that only bilateral talks can be a feasible approach. Secondly, Pakistan's attempts to brand India's human rights violations in Kashmir as "state terrorism" within the new debate on terrorism after 9/11 backfired because India was more successful to blame the ISI's support for Islamist groups. Finally, the Iraq war in 2003, which was justified by the United States because of the alleged support for terrorism and the proliferation of weapons of mass destruction (WMD), was closely followed in Pakistan. At the end of 2003 the network of A.Q. Khan was dismantled, which had proliferated nuclear technology to countries like Iran and Libya.

Musharraf's change led to a remarkable improvement in the relations with India. At the summit in New Delhi in April 2005 Indian Prime Minister Manmohan Singh and President Musharraf declared the peace process to be "irreversible". They further agreed on the basic principles for a solution of Kashmir: Pakistan insisted that the LoC should not be transformed into an international boundary whereas India stressed the principle that the borders of Kashmir should not be changed. The earthquake in Kashmir in October 2005 accelerated the rapprochement. India and Pakistan agreed on crossing points

21 Text of PM, Musharraf statement, in: The Hindu, 7 January 2004. 
for civilians at the LoC which became permeable for the first time since 1947. In August 2007 trade relations were established between the two parts of Kashmir over the LoC that was slowly transformed into a soft border.

The composite dialogue brought new confidence-building measures like the facilitation of travel, new lines of communication and transport between Kashmir, Punjab and Sindh, and better economic, cultural and academic cooperation. Musharraf even suggested the withdrawal of Pakistani troops from Kashmir for the first time. ${ }^{22}$ In July 2007 Prime Minister Manmohan Singh argued for shared use of land and water resources in Kashmir. Back-channel negotiations brought both sides so close to an agreement as never before since $1947 .{ }^{23}$ The difficult domestic situation in Pakistan in 2007 with the siege of the Red Mosque and the dismissal of Chief Justice Iftikhar Chaudhry raised large protests that prevented Musharraf to continue the process.

Musharraf's turn on Kashmir was rejected by radical groups. He evaded several assassination attempts by militant Kashmiris who were supported by members of the armed forces. Moreover, a series of attacks in India by militant groups, like in Delhi in 2005, in Mumbai and Varanasi in 2006 and on the train connection with Pakistan in 2007, aimed to sabotage the rapprochement. The newly elected government of the Pakistan Peoples Party (PPP) supported Musharraf's policy vis-à-vis India when it took power in February 2008. ${ }^{24}$ But after the Mumbai attack in November 2008, which was attributed to the LeT, India suspended the composite dialogue.

The new Chief of Army Staff (COAS) General Kayani who followed Musharraf in November 2007 brought Kashmir back to the centre of the agenda with India. ${ }^{25}$ Moreover, the Kashmir issue was enlarged and was described by radical groups like Jamaat-ud-Dawa (JuD), which is regarded as parent organisation of the LeT, as a resource conflict. India was accused of "water theft" 26 although the water distribution in Punjab had already been settled in 1960 with the Indus Water Treaty under the aegis of the World Bank.

Bringing India and Kashmir back to the centre of Pakistan's foreign policy may also be attributed to the deteriorating situation in the FATA and increasing Western pressure on the Pakistani military. Although the Pakistani army had eliminated and arrested numerous high-ranking Al Qaeda leaders in Pakistan since 2001, it became evident for the Western powers that Pakistan was pursuing different objectives. The return of the Taliban in Afghanistan was only possible because of their safe havens in the FATA. In 2003/04 the Pakistani army started military operations in the FATA that fostered the creation of Pakistani Taliban groups that sought to establish a Taliban state.

22 See "Musharraf offers troop withdrawal," The Hindu, 6 June 2007.

23 "Governments of both countries now have to decide on a time to disclose solution...", interview with Pakistani Foreign Minister Khurshid Kasuri in The Friday Times, 1-7 June 2007, p. 6.

24 See "India, Pak should focus on trade ties: Zardari," The Hindu, 1 March 2008.

25 See Strategic death? in: Daily Times, 3 February 2010; Almeida Cyril, Kayani spells out threat posed by Indian doctrine, in: Dawn, 4 February 2010. 26 See India's 'water theft', in: The News, 8 March 2010.
Pakistan used different political, economic and military strategies in the tribal areas. Politically the government wanted to strengthen again the traditional leaders (Maliks) against the Mullahs. The fight against the Soviet occupation in Afghanistan had increasingly Islamicized the traditional tribal structures in the 1980s. This process continued after 2001 when moderate tribal leaders were killed by Taliban. Economically substantial financial support both by the Pakistani government and the United States sought to improve the infrastructure in the region, which is among the least developed parts of Pakistan. Militarily, the army trained paramilitary units like the Frontier Corps (FC) for counterinsurgency and supported tribal militias (lashkars) in order to fight the Taliban. The army also negotiated various peace agreements with militant tribes in North Waziristan in 2006, but the strategy was unsuccessful to contain the Taliban.

With the formation of the Tehrik-i-Taliban Pakistan (TTP) in December 2007 there are three different militant groupings operating in the FATA. Al Qaeda with its foreign fighters and the TTP are the common enemies of the Pakistani army and the NATO/ISAF forces. Pakistan has deployed more than 100,000 soldiers in the tribal areas and has suffered more than 2,000 casualties since 2001. But the Pakistan army and the Western forces differ in their perception on the Afghan Taliban groups which comprise the Quetta Shura, the Haqqani network and the Hezb-e-Islami of Gulbuddin Hekmatyar. Here, the Pakistani military is faced with a serious dilemma. On the one hand, Pakistan still perceives the Afghan Taliban as assets to secure its strategic interests in Afghanistan. The arrest of Mullah Baradar in spring 2010 did therefore not indicate a change of Pakistan's position towards the Afghan Talibans but was rather an amplification that talks between Taliban and the Karzai government should not be held without Pakistan's consent. ${ }^{27}$ On the other hand, the ideological, political, and tribal links between Al Qaeda, TTP, Afghan Talibans and Kashmiri groups like LeT make it more and more impossible to demarcate clear battle lines between 'good' and 'bad' Taliban. The attacks in the urban centres of Punjab and the army headquarter in autumn 2009 indicate that TTP has established links to Al Qaeda and LeT and could therefore expand its military operations.

In this scenario the perceived Indian threat is an important buffer to bloc increasing Western pressures for a greater military engagement in the tribal areas. In February 2010 General Kayani declared that the Pakistani military is "India centric" and that the concept of "strategic depth" in regard to Afghanistan is still valid. ${ }^{28}$ Therefore, large parts of the Pakistani army are still deployed at the Indian border although the main threat for the Pakistani state and society is emanating from the militant groups in the tribal areas and the Punjab.

The floods of summer 2010 have added another dimension to the already existing complex scenario. The engagement of the military to cope with the floods has at least halted the military campaign in the FATA. The army has always been reluctant to extend the military operations to North Waziristan, which is

\footnotetext{
27 See Christian Wagner, Guido Steinberg, Nils Wörmer, Pakistan gegen die Taliban, Berlin 2010 (SWP-Aktuell 2010/A 30, March 2010).

28 See Strategic death? in: Daily Times, 3 February 2010; Almeida Cyril, Kayani spells out threat posed by Indian doctrine, in: Dawn, 4 February 2010.
} 
regarded as stronghold of the Haqqani network. Moreover, the damage of property and infrastructure has further hit Pakistan's already slow economic development and has given Islamic charity organisations new room for their activities.

\section{Prospects}

The present situation in Pakistan is the unintended outcome of a foreign and security policy of the armed forces that has used non-state actors as strategic assets over years and has linked Afghanistan's conflict with India with the conflict over Kashmir. The regional power play that was successful in the 1990s has backfired to the detriment of Pakistan. But Pakistan's foreign policy discourse remains dominated by the geo-strategic perspectives of the military so that Afghanistan is only seen in the context of the relations with India. An alternative civilian approach would be to promote closer economic cooperation between Afghanistan, Pakistan and India in the framework of the South Asia Free Trade Agreement (SAFTA). The new Afghanistan-Pakistan Transit Trade Agreement (APTTA) was only a half-hearted reform that again illustrated the resistance from sections within the Pakistani establishment, to increase economic relations with India and to transform Afghanistan into a region of cooperation rather than confrontation with India. $^{29}$

29 See Ahmad Hassan, Cabinet approves Afghan transit trade agreement, in Dawn, 7 October 2010

\title{
Pakistan's Afghanistan Policy, Blockades, and Strategic Trade
}

\author{
Julian Schofield*
}

\begin{abstract}
NATO's long-term goal of the socio-economic development of Afghanistan sufficient for it to sustain a national army is imperiled by the conditions of impediments to trade imposed on it by Pakistan. Specifically, since partition of the subcontinent in 1947, disputes over the status of the Pashtun population in the Northwest Frontier Province (NWFP) have led Pakistan to inhibit Indo-Afghan trade, the historical route for Afghan goods. While Pakistan has made concessions in permitting transshipped Afghan exports to India, it has left in place serious impediments to Indian exports to Afghanistan.
\end{abstract}

Keywords: Pakistan, Afghanistan, India, transit trade

Pakistan, Afghanistan, Indien, Transithandel

\section{Introduction}

$\mathrm{N}$ ATO's long-term goal of the socio-economic development of Afghanistan sufficient for it to sustain a national army is imperiled by the conditions of impediments to trade imposed on it by Pakistan. Specifically, since partition of the subcontinent in 1947, disputes over the status of the Pashtun population in the Northwest Frontier Province (NWFP) have led Pakistan to inhibit Indo-Afghan trade, the historical route for Afghan goods. These blockades were imposed in 1947, 1955, 1961, and to a lesser extent, 1965, and persisted until 2009. They were extended to all transit through the Khyber Pass and Karachi, Pakistan's principal

\footnotetext{
* Julian Schofield (Ph.D. Columbia) is associate professor of political science at Concordia University (Montreal). Author of Militarization and War (Macmillan 2007), and articles and chapters on Pakistan, Schofield has conducted field work in South Asia six times since 1999. This article is doubleblind peer-reviewed.
}

port. ${ }^{1}$ More broadly, Pakistan's exercise of strategic trade with Afghanistan is a component of its regional policy in its rivalry with India and Afghanistan's traditional alignment with New Delhi. While Pakistan has made concessions in permitting transshipped Afghan exports to India, it has left in place serious impediments to Indian exports to Afghanistan. This article will examine the causes of Pakistan's strategic trade policy with Afghanistan, its manifestation, and prospects for change.

In retaliation against Afghan refusals to diplomatically recognize Pakistan in 1947, and repudiation of earlier AfghanBritish treaties, Pakistan imposed an unofficial trade embargo that has been in effect since, denying Afghan access to its natural markets in India, with all its concomitant drag effects on socio-economic development. Though Pakistan accepts

1 Hasan Ali Shah Jafri, Indo-Afghan Relations 1947-67, New Delhi, Sterling Publishers Private Limited, 1976, pp. 42-43, 119-120; Frederic Grare, Pakistan and The Afghan Conflict, 1970-1985, Oxford, Oxford University Press, 2003, pp. 2-9. 